\title{
Growth performance of silver carp (Hypophthalmichthys molitrix) in cage stocked at different densities
}

\author{
Rumana Akhtar Jui, Mohammad Mahfujul Haque and S. M. Rahmatullah
}

Department of Aquaculture, Bangladesh Agricultural University, Mymensingh-2202, Bangladesh

\section{ARTICLE INFO}

Article history:

Received: 11 February 2018

Accepted: 11 August 2018

\section{Keywords:}

Silver carp, Cage, Stocking density, Growth parameters, Economic efficiency

Correspondence:

Rumana Akhtar Jui

(rumanajui@yahoo.com)

\begin{abstract}
An experiment was conducted to evaluate the growth performance of silver carp (Hypophthalmichthys molitrix) in cage stocking at different densities. It was expected that silver carp could grow feeding on plankton without external feeding. In this experiment, silver carps in nine cages were stocked in three different stocking densities such as 20,30 and 40 fishes $/ \mathrm{m}^{3}$ designated as treatments $T_{1}, T_{2}$ and $T_{3}$, which were located in the south west corner of the L-shaped pond in Field Laboratory Complex, Faculty of Fisheries, Bangladesh Agricultural University (BAU), Mymensingh consisting of three treatments with three replications of each for a period of 90 days from $18^{\text {th }}$ August to $17^{\text {th }}$ November, 2015. Each cage size was $1 \mathrm{~m} \times 1 \mathrm{~m} \times 1 \mathrm{~m}$ (length $\mathrm{x}$ width $\mathrm{x}$ height) and silver carp was cultured in the cage with natural feed which filtered phytoplankton mainly. Twenty five genera of phytoplankton were identified in pond and the average phytoplankton production was around $8.44 \times 10^{5}$ cells/liter. Water quality parameters such as temperature, dissolved oxygen, $\mathrm{pH}$ and transparency were recorded fortnightly. At the completion of the experiment, weight showed significant difference ( $>0.05)$ among three treatments although length didn't vary significantly. The highest length gain $(18.61 \pm 0.369 \mathrm{~cm})$ and the highest weight gain $(62.52+2.249 \mathrm{~g})$ were found in $\mathrm{T}_{1}$. The highest SGR\% for silver carp was found in $\mathrm{T}_{1}$ and the highest total production was obtained in $T_{3}\left(5.00 \pm 0.015 \mathrm{~kg} / \mathrm{m}^{3}\right)$. Individual growth performance of silver carp was satisfactory. Further studies are needed with different stocking densities and duration to verify the result.
\end{abstract}

\section{Introduction}

Different types of fish species are cultured in Bangladesh like Indian major carps, Chinese carps, indigenous catfish, Thai pangus, koi, tilapia etc. Among them, silver carp (Hypophthalmichthys molitrix) has become one of the most important commercial culturable species and it is a freshwater cyprinid fish originated from Eurasia (FRSS, 2017). Silver carp is generally considered as a planktivorous fish (Cremer and Smitherman, 1980; Spataru et al., 1983). The effect of filter-feeding fish on the plankton communities of aquatic ecosystem have been studied by Zhang et al. (2006); Milstein et al. (2008); Yan et al. (2009) and Wahab et al., 2011). The culture of silver carp in cage has shown promising production without external feeding as this species living the cage can filter plankton horizontally from the water body (Roy, 2015). The culture of fish in cages is a promising aquaculture technology that has already proven itself in many Asian countries. However, cage culture is a relatively novel concept in Bangladesh. Cage culture is a viable alternative to traditional techniques of rearing, due to its practicability and mainly low costs (Beveridge, 1996). Cages are easy to manage, produce fish of high quality and utilize existing water bodies (Beveridge, 1996). Therefore, cage aquaculture offers a viable alternative for the landless and poor farmers in Bangladesh. Cage culture of fish consists of raising a group of fish from the juvenile stage to the table size in a volume of water enclosed with all sides, including the bottom, while permitting the free circulation of water through the cage culture. It can be practiced intensively in low productive water bodies. It permits manipulation of harvest to fit the market whenever more profitable. Thus it could be very profitable for poor farmers (CARE, 2000).

In Bangladesh, intensive monoculture is increasingly being practiced. In this culture system, farmers stock the fish at high densities and offer large quantity of feed for getting higher profit within short time, which resulted in excessive accumulation of metabolic and feed wastes in the pond bottom. The decomposition of these metabolic and feed wastes make the pond water nutrient rich that favor the excessive growth of phytoplankton (Haque and Sarkar, 2006). Silver carp mainly phytoplanktivore and it has short food chain and higher efficiency at converting primary production into fish protein than that of carnivorous fish. Cage culture of silver carp has the potential to use phytoplankton from the ponds where primary productivity is higher and ponds have multiownership problems to bring into aquaculture practices. Considering above facts, the present study was carried out to assess effects of stocking density on the growth performance of silver carp in cage stocking at different densities. 


\section{Materials and Methods}

\section{Study site}

The experiment was conducted in the pond at south-west side of Field Laboratory Complex, Faculty of Fisheries, BAU, Mymensingh. (Fig. 1) It is a L- shaped pond and the depth was 1 meter where the cages were set.

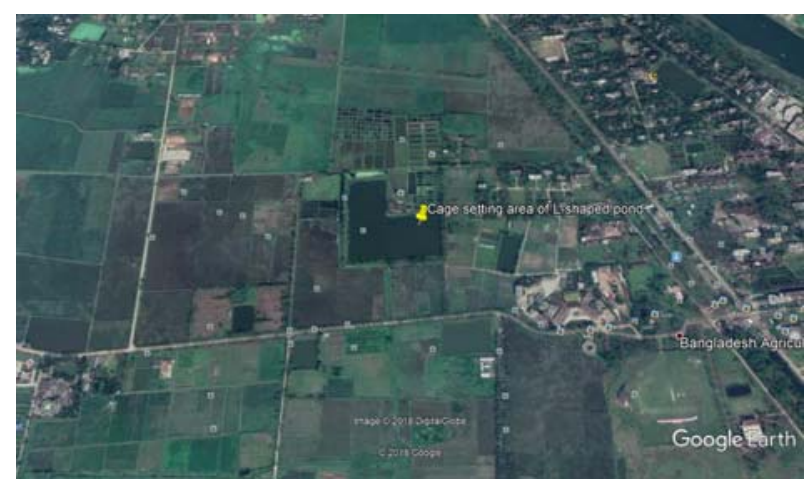

Fig. 1. Google earth map showing cage location in the Lshaped pond of Field Laboratory Complex, Faculty of Fisheries, BAU, Mymensingh

\section{Experimental design}

The experimental design comprised of three densities (20, 30 and 40 fishes $/ \mathrm{m}^{3}$ ), carried out with three replication in each densities, using nine cages. The treatments were named as: $\mathrm{T}_{1}$ (20 fish $/ \mathrm{m}^{3}$ : cage 1,2 and 3), $\mathrm{T}_{2}$ (30 fish $/ \mathrm{m}^{3}$ : cage 4,5 and 6$)$ and $\mathrm{T}_{3}(40$ fish $/ \mathrm{m}^{3}$ : cage 7, 8 and 9) (Table 1). The experiment was continued for 90 days from $18^{\text {th }}$ August to $17^{\text {th }}$ November, 2015. Fish fingerlings were collected from Bangladesh Fisheries Research Institute (BFRI).

Table 1. The layout of the experiment

\begin{tabular}{cccc}
\hline $\begin{array}{c}\text { Treatment } \\
\left.\text { Density (fish } / \mathrm{m}^{3}\right)\end{array}$ & Replication & $\begin{array}{c}\text { Cage } \\
\text { No. }\end{array}$ & $\begin{array}{c}\text { Initial body } \\
\text { weight }(\mathrm{g})\end{array}$ \\
\hline $\mathrm{T}_{1}$ & 3 & 1 & \\
$\left(20 \mathrm{fish} / \mathrm{m}^{3}\right)$ & & 2 & 10.31 \\
& & 3 & \\
$\mathrm{~T}_{2}$ & 3 & 5 & 10.31 \\
$\left(30 \mathrm{fish} / \mathrm{m}^{3}\right)$ & & 6 & \\
& & 7 & \\
$\mathrm{~T}_{3}$ & 3 & 8 & 10.31 \\
$\left(40 \mathrm{fish} / \mathrm{m}^{3}\right)$ & & 9 & \\
\hline
\end{tabular}

\section{Study on phytoplankton}

Both qualitative and quantitative observations were done to examine planktons. Phytoplankton was identified using a light microscope (Primo Star, USA). Quantitative study of phytoplankton was done by Sedge wick-Rafter cell (S-R cell).

\section{Plankton collection and sampling procedure}

Plankton samples were collected from the experimental pond where the cages were set. Five liters of water were passed through the plankton net to get a $50 \mathrm{ml}$ sample. The sample was preserved immediately with 5\% formalin in a bottle. Before counting the S-R cell was allowed to stand for at least 15 minutes to settle the planktons. The cell was then set on an electric microscope. 10 fields from the total 1000 fields were randomly chosen for counting.

For counting phytoplankton, the following formula was used (Rahman, 1992).

$\mathrm{N}=\frac{\mathrm{A} \times 1000 \times \mathrm{C}}{\mathrm{V} \times \mathrm{F} \times \mathrm{L}}$

Where,

$\mathrm{N}=$ No. of phytoplankton cells per liter

$\mathrm{A}=$ Total No. phytoplankton counted

$\mathrm{C}=$ Volume of final concentration of samples in $\mathrm{ml}$

$\mathrm{V}=$ Volume of a field in cubic millimeter

$\mathrm{F}=$ Number of the fields counted

$\mathrm{L}=$ Volume of original water in liter

\section{Water quality parameters}

The water quality parameters were recorded during sampling. Water temperature $\left({ }^{\circ} \mathrm{C}\right)$, dissolved oxygen (ppm), $\mathrm{pH}$, transparency were recorded by using portable instruments.

\section{Growth performance}

Sampling was done 15 days interval by scoop net. In every sampling, 3 fishes were collected randomly from each treatment and their individual length and body weight were recorded. After harvesting of fishes final weight were recorded and following parameters were used to evaluate the growth and production of the fishes. Length gain $(\mathrm{cm})=$ Mean final length $(\mathrm{cm})$ - Mean initial length $(\mathrm{cm})$

Weight gain $(\mathrm{g})=$ Mean final weight $(\mathrm{g})$ - Mean initial weight (g)

Percent $(\%)$ weight grain $=$

$\frac{\text { Mean final weight }(\mathrm{g})-\text { Mean initial weight }(\mathrm{g})}{\text { Mean initial weight }(\mathrm{g})} \times 100$

Specific growth rate SGR $(\%$ day $)=$

$$
=\frac{\log \mathrm{W}_{2}-\log \mathrm{W}_{1}}{\mathrm{~T}_{2}-\mathrm{T}_{1}} \times 100
$$

Here,

$\mathrm{W}_{2}=$ Mean final weight $(\mathrm{g})$

$\mathrm{W}_{1}=$ Mean initial weight ( $\mathrm{g}$ )

$\mathrm{T}_{2}=$ Time at end of the experiment

$\mathrm{T}_{1}=$ Time at start of the experiment

\section{Average daily gain (ADG)}

Average daily gain was computed by subtracting the initial body weigh from the final body weight and then dividing by the number of days of culture. 
ADG $=\frac{\text { Mean final fish weight }- \text { Mean initial fish weight }}{\text { Number of days of culture }}$

Survival rate $=\frac{\text { No. of fish harvested }}{\text { No. of fish stocked }} \times 100$

\section{Total production}

The production of silver carp was determined by multiplying the average gain in weight $(\mathrm{kg})$ by the total number of fishes survived at the end of the experiment.

\section{Data analysis}

The data found during the investigation were entered into MS Excel 2010. The significant differences among three treatments for silver carp in cages were tested using oneway ANOVA. All the statistical tests were done by SPSS (Statistical Package for the Social Sciences) software version 16.

\section{Results}

\section{Production of phytoplankton}

As the cages were set in the same pond, during the sampling the abundance of phytoplankton groups in three treatments were more less same. Five major groups and twenty five genera of phytoplankton were identified of which included Bacillariophyceae (6 genera), Chlorophyceae (12 genera), Cyanophyceae (4 genera), Euglenophyceae (2 genera) and Rodophyceae (1 genus) (Table 2).

Table 2. Generic status with the different groups of phytoplankton

\begin{tabular}{cl}
\hline Groups & \multicolumn{1}{c}{ Genera } \\
\hline & Cyclotella \\
& Diatoma \\
& Navicula \\
Bascillariophyceae & Amphora \\
& Asterionella \\
& Nitzschia \\
& Actinastrum \\
& Crucigenia \\
& Chlorella \\
& Vlovox \\
& Closterium \\
& Cosmarium \\
Pediastrum \\
Chlorophyceae & Scenedesmus \\
& Ulva \\
& Ulothrix \\
& Tetraedron \\
& Characium \\
& Anabaena \\
Euglenophyceae & Microcystis \\
& Ehlorococcus \\
& Phacus \\
& Porphyra \\
\hline &
\end{tabular}

In the experimental period, the average phytoplankton production was around $8.44 \times 10^{5}$ cells/litre. Among different phytoplankton groups, Chlorophyceae was found dominating with $52 \%$ of the total count (Table 3 and Fig. 2).

Table 3. Phytoplankton content of water in cage set in the pond

\begin{tabular}{lc}
\hline \multicolumn{1}{c}{ Groups } & Amount (cells/liter) \\
\hline Bacillariophyceae & 214000 \\
Chlorophyceae & 440000 \\
Cyanophyceae & 131000 \\
Euglenophyceae & 46000 \\
Rhodophyceae & 13000 \\
\hline Total & $=8.44 \times 10^{5}$ cells/liter \\
\hline
\end{tabular}

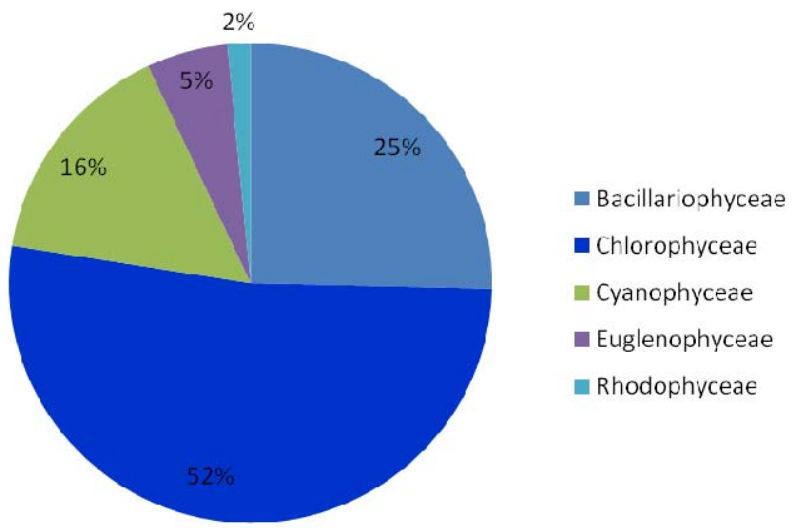

Fig. 2. Percent distribution of different phytoplankton groups in cage water

\section{Water quality parameters}

The mean values of water quality parameters are presented in the Table 4 that did not show any significant difference among the treatments.

Table 4. Average (Mean $\pm \mathrm{SE}$ ) value of water quality parameters in different treatments

\begin{tabular}{ccccc}
\hline Treatments & $\begin{array}{c}\text { Temperature } \\
\left({ }^{\circ} \mathrm{C}\right)\end{array}$ & $\begin{array}{c}\text { Dissolved } \\
\text { oxygen } \\
(\mathrm{mg} / \mathrm{l})\end{array}$ & $\mathrm{pH}$ & $\begin{array}{c}\text { Transpa- } \\
\text { rency } \\
(\mathrm{cm})\end{array}$ \\
\hline $\mathrm{T}_{1}$ & $30.50 \pm 0.61$ & $6.50 \pm 0.49$ & $7.04 \pm 0.27$ & $31 \pm 0.53$ \\
$\mathrm{~T}_{2}$ & $30.34 \pm 0.44$ & $6.00 \pm 0.47$ & $8.27 \pm 0.03$ & $32 \pm 0.62$ \\
$\mathrm{~T}_{3}$ & $31.46 \pm 0.51$ & $6.33 \pm 0.58$ & $8.50 \pm 0.06$ & $32 \pm 0.67$ \\
\hline
\end{tabular}

\section{Growth performance and survival rate}

Length gain (cm): During the study period, length gain (cm) of silver carp was higher in $\mathrm{T}_{1}$ in comparison with $\mathrm{T}_{2}$ and $\mathrm{T}_{3}$ (Table 5). Statistically, there is no significant difference ( $>0.05)$ among the treatments for length gain in silver carp (Table 5). 
Table 5. Growth performance and survival rate of silver carp in cage culture under different treatments

\begin{tabular}{|c|c|c|c|c|c|c|c|c|c|}
\hline Species & Treatment & $\begin{array}{l}\text { Initial } \\
\text { length }\end{array}$ & $\begin{array}{l}\text { Final length } \\
(\mathrm{cm})\end{array}$ & $\begin{array}{c}\text { Length } \\
\text { grain }(\mathrm{cm})\end{array}$ & $\begin{array}{c}\text { Initial } \\
\text { weight (g) }\end{array}$ & $\begin{array}{l}\text { Final weight } \\
(\mathrm{g})\end{array}$ & $\begin{array}{l}\text { Weight gain } \\
\text { (g) }\end{array}$ & $\%$ weight gain & $\begin{array}{l}\text { Survival } \\
\text { rate (\%) }\end{array}$ \\
\hline \multirow{3}{*}{$\begin{array}{l}\text { Silver } \\
\text { carp }\end{array}$} & $\mathrm{T}_{1}$ & $10.36 \pm 0.000$ & $18.61 \pm 0.369$ & $8.25 \pm 0.369$ & $10.31 \pm 0.000$ & $62.52 \pm 2.249$ & $52.21 \pm 2.249$ & $455.79 \pm 19.632$ & $79.23 \pm 1.118$ \\
\hline & $\mathrm{T}_{2}$ & $10.36 \pm 0.000$ & $17.79 \pm 0.336$ & $7.43 \pm 0.336$ & $10.31 \pm 0.000$ & $51.75 \pm 1.596$ & $41.44 \pm 1.596$ & $361.77 \pm 13.928$ & $77.67 \pm 9.200$ \\
\hline & $\mathrm{T}_{3}$ & $10.36 \pm 0.00$ & $17.74 \pm 0.717$ & $7.38 \pm 0.717$ & $10.31 \pm 0.000$ & $49.49 \pm 0.930$ & $39.18 \pm 0.930$ & $341.99 \pm 0.930$ & $70.36 \pm 0.575$ \\
\hline
\end{tabular}

Weight gain (g): During the study period, weight gain (g) of silver carp was higher in $\mathrm{T}_{1}$ in comparison with $\mathrm{T}_{2}$ and $\mathrm{T}_{3}$ (Table 5). Similarly, the highest percent (\%) weight gain of silver carp was found in $\mathrm{T}_{1}$ compared to $\mathrm{T}_{2}$ and $\mathrm{T}_{3}$ (Table 5). There were significant differences $(\mathrm{p}<0.05)$ among the three treatments for weight gain and $\%$ weight gain in silver carp.

Specific growth rate (SGR \%) of silver carp: The specific growth rate (SGR \%) of silver carp were significantly varied $(\mathrm{p}<0.05)$ among the three treatments (Table 5 and Fig. 3).

Table 6. Specific growth rate (SGR \%) of silver carp

\begin{tabular}{lcccc}
\hline & \multirow{2}{*}{ Species } & \multicolumn{3}{c}{ Treatment } \\
\cline { 3 - 5 } & & $\mathrm{T}_{1}$ & $\mathrm{~T}_{2}$ & $\mathrm{~T}_{3}$ \\
\hline SGR (\%) & Silver & $180.20 \pm 3.561$ & $161.31 \pm 3.100$ & $156.85 \pm 1.881$ \\
SGR & Carp & & & \\
(\%/day) & $\begin{array}{c}\text { Silver } \\
\text { carp }\end{array}$ & $0.020 \pm 0.000$ & $0.018 \pm 0.000$ & $0.017 \pm 0.000$ \\
\hline
\end{tabular}

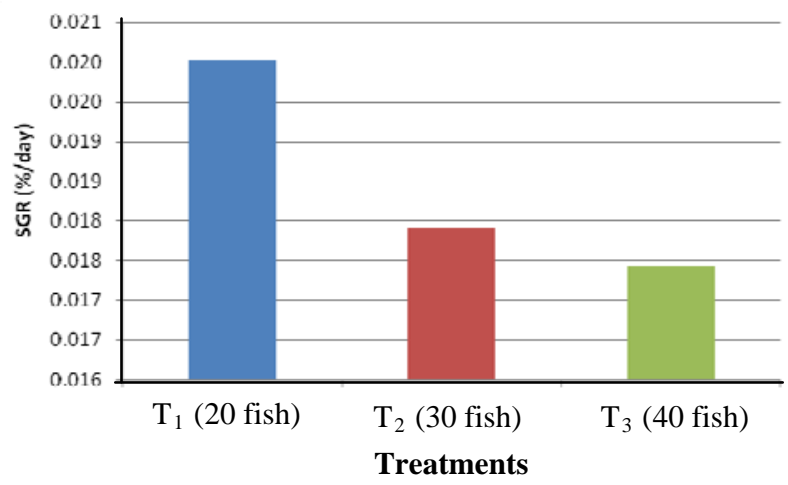

Fig. 3. Specific growth rate (SGR\%) of silver carp at different stocking densities (where, $\mathrm{T}_{1}, \mathrm{~T}_{2}$ and $\mathrm{T}_{3}$ implies 20, 30 and $40 \mathrm{fish} / \mathrm{m}^{3}$, respectively).

Individual growth performance of weight (g) of silver carp: The weight gain of silver carp was recorded highest in $T_{1}(52.21+2.249 \mathrm{~g})$ and lowest in $T_{3}$ (39.18+0.930 g).

Survival rate: The survival rate of silver carp in cage was highest in $T_{1}(79.23 \pm 1.118)$ and lowest in $T_{3}$ (70.36+0.575) (Table 5).

\section{Total production}

The net production of fish in treatments $T_{1}, T_{2}$ and $T_{3}$ were $2.16+0.01 \mathrm{~kg} / \mathrm{m}^{3}, 3.90+0.02 \mathrm{~kg} / \mathrm{m}^{3}$ and $5.00+0.015$ $\mathrm{kg} / \mathrm{m}^{3}$, respectively. The highest total production was found $5.00 \pm 0.015 \mathrm{~kg} / \mathrm{m}^{3}$ in $\mathrm{T}_{3}$ due to higher stocking density and the lowest $2.16 \pm 0.01 \mathrm{~kg} / \mathrm{m}^{3}$ was found in $\mathrm{T}_{1}$ due to lower stocking density ( Fig. 4).

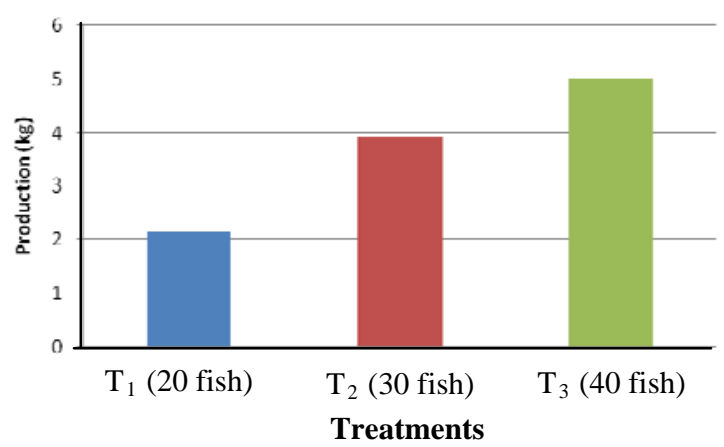

Fig. 4. Production of silver carp among three treatments in different sampling stage

\section{Discussion}

\section{Plankton production}

Phytoplankton production of the experimental pond was found to be consisted of five major phytoplanktonic groups, which included Bacillariophyceae, Chlorophyceae, Cyanophyceae, Euglenophyceae and Rodophyceae. The most dominant group was Chlorophyceae. More or less similar results were obtained by Haque et al. (1998), Paul (1998), Chowdhury (1999) and Yeamin (2000).

Twenty five genera of phytoplankton were found from the experimental pond of the study. Nirod (1997) studied plankton population in nine experimental ponds of Fisheries Field Laboratory, BAU, Mymensingh and found 25 genera of phytoplankton belonging to Bacillariophyceae (3), Chlorophyceae (15), Euglenophyceae. Similar results were found by Paul (1998), Yeamin (2000), Raihan (2001), and Kohinoor (2000). These sorts of phytoplankton are good food of indigenous and exotic carps such as Labeo rohita, Cirrhinus cirrhosus, Hypophthalmichthys molitrix, and Oreochromis niloticus. The presence of such types of phytoplankton in the pond reflected higher growth of silver carp (Haque, 2007).

\section{Water quality parameters}

Environmental parameters exert an immense influence on the maintenance of a healthy aquatic environment and production of food organism. Fish growth, metabolism and other biological activities are mostly dependent on water temperature so temperature is one of the vital water quality parameters for fish culture. The mean values of water temperature were $30.50 \pm 0.61^{\circ} \mathrm{C}$, 
$30.34 \pm 0.44{ }^{\circ} \mathrm{C}$ and $31.46 \pm 0.51{ }^{\circ} \mathrm{C}$ in $\mathrm{T}_{1}, \mathrm{~T}_{2}$ and $\mathrm{T}_{3}$, respectively. The maximum temperature $\left(32^{\circ} \mathrm{C}\right)$ was recorded in $\mathrm{T}_{2}$ on $18^{\text {th }}$ August due to high intensity of sunlight and absent of cloud in the sky. The lowest temperature $\left(18^{\circ} \mathrm{C}\right)$ was recorded in $\mathrm{T}_{3}$ on $17^{\text {th }}$ November due to low intensity of sunlight. Hasan (2007) measured water temperature in ponds of BAU campus, Mymensingh and found the range from 21 to $32.8^{\circ} \mathrm{C}$ which was more or less similar to this study. Another vital water quality parameter is dissolved oxygen on which fish depend on to live. Shortage of dissolved oxygen in water, fish start gulping. Sustainable fish culture depends on the optimum level of dissolved oxygen concentration. In this study the mean values of dissolved oxygen concentration were $6.50 \pm 0.49 \mathrm{ppm}$ in $\mathrm{T}_{1}, 6.00 \pm 0.47 \mathrm{ppm}$ in $\mathrm{T}_{2}$ and $6.33 \pm 0.58 \mathrm{ppm}$ in $\mathrm{T}_{3}$. Bhatnagar and Devi (2013) reported that the desirable dissolved oxygen of $5 \mathrm{ppm}$ which was slightly lower than the present study. The $\mathrm{pH}$ is another productivity index of water body. The circum-neutral $\mathrm{pH}$ or slightly alkaline $\mathrm{pH}$ is most suitable for fish culture. For pond fish culture, the suitable range of $\mathrm{pH}$ is 6.5 to 8.5 (Byod, 2008). During the experimental period the mean values of $\mathrm{pH}$ were $7.04 \pm 0.27,8.27 \pm 0.03$ and $8.50 \pm 0.06$ in $\mathrm{T}_{1}$, $\mathrm{T}_{2}$ and $\mathrm{T}_{3}$, respectively. Sarker (2000) and Maghna (2012) measured $\mathrm{pH}$ in ponds of BAU campus, Mymensingh and found to vary between 6.8 to 8.3 and 7.6 to 8.3 , respectively which were relevant in the present study. Water transparency is a gross measure of pond productivity. When the abundance of phytoplankton in a water body, the secchi disk reading becomes lower and vice-versa. Boyd (1982) suggested a transparency $(\mathrm{cm})$ ranges $15-40 \mathrm{~cm}$ is good for fish culture. The concentration of transparency in the present study varied from the $31 \pm 0.53 \mathrm{~cm}, 32 \pm 0.62 \mathrm{~cm}$ and $32 \pm 0.67 \mathrm{~cm}$ in $T_{1}, T_{2}$ and $T_{3}$, respectively that ranged corresponds to the study of Boyd (1982).

\section{Growth parameters}

Weight gain: In the present study, the length gain of silver carp were $8.25 \pm 0.369 \mathrm{~cm}, 7.43 \pm 0.336 \mathrm{~cm}$ and $7.38+0.717 \mathrm{~cm}$ for $\mathrm{T}_{1}, \mathrm{~T}_{2}$ and $\mathrm{T}_{3}$, respectively.

The weight gain of silver carp was $52.21 \pm 2.249 \mathrm{~g}$, $41.44 \pm 1.596 \mathrm{~g}$ and $39.18 \pm 0.930 \mathrm{~g}$ for $\mathrm{T}_{1}, \mathrm{~T}_{2}$ and $\mathrm{T}_{3}$, respectively in cages which was slightly lower than the findings of Nazish (2011) who recorded total body weight gain was 86.2 to $124.3 \mathrm{~g}$ in different ponds. The total growth performance of silver carp was relatively low because in cage silver carp was grown up only with natural feed. Diana et al. (2004) reported that sex reversed Nile tilapia stocked in ponds at a low density showed better growth than at a higher stocking density. Similarly in cages of silver carp we found the higher weight gain at lower stocking densities. In $\mathrm{T}_{1}$ (20 fish $/ \mathrm{m}^{3}$ ) weight gain was higher than in $T_{2}\left(30 \mathrm{fish} / \mathrm{m}^{3}\right)$ and $\mathrm{T}_{3} \quad\left(40 \mathrm{fish} / \mathrm{m}^{3}\right)$, because the competition of phytoplankton which they feed was low in lower stocking density.
Specific growth rate (SGR \%): The values of specific growth rate of silver carp were observed at $0.020 \pm 0.000$, $0.018 \pm 0.000$ and $0.017 \pm 0.000$ in $T_{1}, T_{2}$ and $T_{3}$, respectively. The highest specific growth rate $(0.020)$ was observed in $T_{1}$ and the lowest specific growth rate $(0.017)$ was observed in $T_{3}$. In the present study, the values were lower than the finding of Ali et al. (2009) who recorded SGR of silver carp ranged from 0.52 to 0.53 in different treatments.

Survival rate and total production: The survivability of silver carp was observed as $79.23 \%$ in $\mathrm{T}_{1}, 77.67 \%$ in $\mathrm{T}_{2}$ and $70.36 \%$ in $\mathrm{T}_{3}$ in first two weeks. This indicates the fundamental relationship between the stocking density and survival rate in cage in ponds. The variation of production of fish was found in three treatments. Among them, the higher production of fish was observed in $T_{3}$ where stocking density was $40 \mathrm{fish} / \mathrm{m}^{3}$. The lowest production was observed in $\mathrm{T}_{1}$ where stocking density was $20 \mathrm{fish} / \mathrm{m}^{3}$. Singh et al. (2013) obtained $0.214 \mathrm{~kg} /$ $\mathrm{m}^{3}$ production for different three stocking densities (2.5, 3.0, $4.0 \mathrm{fish} / \mathrm{m}^{3}$ ) in carp polyculture during 120 days culture period. The fish production recorded in the present study was $2.16 \pm 0.01 \mathrm{~kg} / \mathrm{m}^{3}, 3.90 \pm 0.02 \mathrm{~kg} / \mathrm{m}^{3}$ and $5.00 \pm 0.015 \mathrm{~kg} / \mathrm{m}^{3}$ in treatments $\mathrm{T}_{1}, \mathrm{~T}_{2}$ and $\mathrm{T}_{3}$, respectively which was greater than the study of Singh et al. (2013). This was possibly due to following higher stocking density of silver carp in the present experiment.

Relationship between primary productivity and fish growth: Smith (1988) and Radke and Kahl (2002) reported that silver carps are effective in reducing largesized phytoplankton biomass in aquaculture ponds. In this experiment, it was found around $8.44 \times 10^{4}$ cells/liter plankton in the pond. Silver carp was grown up with filtered planktons from water body. In the cage water set in pond, the abundance of Chlorophyceae and other groups of phytoplankton indicates sufficient amount of food organisms available in the pond water for growth and production of silver carp. In this kind of water body abundant with phytoplankton, silver carp is an ellicient fish species that can grow up filtering plankton. Final weight of silver carp with natural feeding (plankton) was satisfactory level in a short culture period. In fact, if it is implemented at the farmer level, this type of technique can ensure the cheaper production of fish.

\section{Conclusion}

Cage culture is one of the fastest growing methods of cultured fish which requires small amount of capital investment and make profit within some months. In this method, landless people can grow fish in cages. In cage aquaculture, the owners of the cages are the owners of the fish within the pond and this is one of the advantages where there is multiple ownership problems in traditional pond management. In cage, silver carp survived with phytoplankton and grown up. In the present study, the growth and production of silver carp was satisfactory in three different densities with natural feed phytoplankton. From the above discussion, it was 
found that cage culture may have impacts in providing extra aquaculture opportunities in water body which is more beneficial for farmer as the additional feeding cost can be saved by this technique.

\section{References}

Ali, H., Talukder, M.B.A., Alam, M.S., Khan, M., Shariful, M.I. and Anisuzzaman, M., 2009. Effects of organic fertilizers on the growth and production performance of exotic carps in polyculture system. B. Res. Pub. Journal, 2: 585-591.

BBS, 2017. Statistical year book of Bangladesh, Ministry of Planning, Government of the People's Republic of Bangladesh.

Bhatnagar, A. and Devi, P., 2013. water quality guidelines for the management of Pond fish culture. Int. J. Env. Science, 3(6): 1980-2009.

Boyd, C.E., 2008. Pond Bottom Soil Analysis, Translated from Global Aquaculture Advocate, 11:91-92, September-October 2008.

Beveridge, M.C.M., 1996. Cage Aquaculture, Fishing News Books, Oxford. pp. 346.

Boyd, C.E., 1982. Water quality management for pond fish culture. Elsevier Science Publishing Company. New York, United States of America. pp. 318

CARE, 2000. Successful Cage Aquaculture in Bangladesh, Care Bangladesh. pp. 3-28.

Chowdhury, F.A., 1999.Effects of Hypophthalmichthys molitrix and Catla catla on the growth, survival and yields of Amblypharyngodon mola in mixed culture, MS Thesis, Department of Fisheries Management, BAU, Mymensingh, Bangladesh.

Cremer, M.C. and Smitherman, R.O., 1980. Food habits and growth of silver and bighead carp in cages and ponds. Aquaculture, 20: $57-64$.

DoF, 2017. Fish Fortnight Compendium, DoF, Ministry of Fisheries and Livestock, Government of the People's Republic of Bangladesh.

Diana, J.S., Yi, Y. and Lin, C.K., 2004. Stocking densities and fertilization regimes for Nile tilapia (Oreochromis niloticus) production in ponds with supplemental feeding. In: Bolivar, R., Mair, G. and Fitzsimmons, K., (Eds.) proceedings of the Sixth International Symposium on Tilapia in Aquaculture, Manila, BFAR, Philippines, pp. 487-499.

FRSS, 2017. Yearbook of Fisheries Statistics of Bangladesh. Fisheries Resources Survey System ( FRSS), DoF, Bangladesh. Vol 2, pp. 124.

FAO, 2016. The state of world Fisheries and Aquaculture. Food and Agriculture Organization of the United Nations. Rome, Italy, pp. 190.

Haque, M.A., 2007. Comparative study on plankton community in ponds between tilapia monoculture and tilapia carp polyculture, MS Thesis, Department of Aquaculture, BAU, Mymensingh, Bangladesh.

Hasan, S.J., 2007. Effects of stocking density on growth and production of GIFT Tilapia (Oreochromis niloticus), MS Thesis, Department of Aquaculture, BAU, Mymensingh, Bangladesh.

Haque, M.M. and Sarkar, M.R.U. 2006. Evaluation of growth and water quality in pangasid catfish (Pangasius hypophthalmus) monoculture and polyculture with silver carp (Hypophthalmichthys molitrix). J.BAU, 4(2): 339-346.

Haque, M.S., Wahab, M.A., Wahid, M.I. and Haq, M.S., 1998. Impacts of Thai silver barb (Puntius gonionotus) Bleeker inclusion in the polyculture of carps. B. J. Fisheries, 2: $15-22$.

Kohinoor, A.H.M., 2000. Development of culture technology of three small indigenous fish mola (Amblypharyngodon mola), punti (puntius sophore) and chela (Chela cachius) with notes on some aspects of their biology. phD Thesis, Department of Fisheries Management, BAU, Mymensingh, Bangladesh.

Maghna, M.S.A., 2012. Studies on the stocking density of hormone treated tilapia (Oreochromis niloticus) fry, MS Thesis, Department of Aquaculture, BAU, Mymensingh, Bangladesh.

Milstein, A., Kadir, A. and Wahab, M.A., 2008. The effects of partially substituting indian carps or adding silver carp on polyculture of large carps and small indigenous fish species. Aquaculture, 279: 92-98.

Nazish, N. and Mateen, A., 2011. Winter growth of carps under different semi-intensive culture conditions. P. Vet. Journal, 31(2) : 134-136.

Nirod, D.B., 1997. Effect on stocking density on growth and production of mola. MS Thesis, Department of Fisheries Management, BAU, Mymensingh, Bangladesh.

Paul, S., 1998. Comparison between carp polyculture system with silver carp (Hypophthalmichthys molitrix) and with small indigenous fish mola(Amblypharyngodon mola), MS Thesis, Department of Fisheries Management, BAU, Mymensingh, Bangladesh.

Roy, A., 2015. A study on the growth and production of tilapia in pond, and silver carp in cage under pond-cum-cage culture system, MS Thesis, Department of Aquaculture , BAU, Mymensingh, Bangladesh.

Radke, R.J. and Kahl, U., 2002. Effects of a filter-feeding fish [silver carp, Hypophthalmichthys molitrix x (val.)] on phyto- and zooplankton in a mesotrophic reservoir: results, from an enclosure experiment. Freshwat. Biol., 47: 2337-2344.

Raihan, A. 2001. To assess the effects of adding punti (Puntius sophore) and mola (Amblypharhyngodon mola) in carp polyculture, MS Thesis, Department of Fisheries Management, BAU, Mymensingh, Bangladesh.

Rahman, M.S., 1992. Water quality management in aquaculture, BRAC prokashana, Dhaka 1212. pp 84.

Singh, U.P., Pandey, N. N. and Bisht, H. C. S., 2013. Growth performance of exotic carps in poultry waste recycled ponds. Int. J. Adv. Res., Vol 1, pp. 239-248.

Sarker, M.N., 2000. Effects of periphyton on monoculture of Gift Tilapia, MS Thesis, Department of Fisheries Management, BAU, Mymensingh, Bangladesh.

Smith, D.W., 1988. phytoplankton and catfish culture: a review. Aquaculture, 74: 167-189.

Spataru, P., Wohlfarth, G.W. and Hulata, G., 1983. Studies on the natural food of different fish species in intensively manuredpolyculture ponds. Aquaculture, 35: 283-298.

Wahab, M.A., Kadir, A., Milstein, A. and Kunda, M., 2011. Manipulation of species combination for enhancing fish production in polyculture systems involving major carps and small indigenous fish species. Aquaculture, 321: 289297.

Yan, L., Zhang, M.G., Liu, Q. and Li, J., 2009. Optimization of culturing the freshwater pearl mussels, Hyriopsis cumingii with filter feeding Chinese carps (bighead carp and silver carp) by orthogonal array design. Aquaculture, 292: 60-66.

Yeamin, H.M., 2000. Effects of iso phoaphorus organic and inorganic fertilizer on water quality parameters and biological production, MS Thesis, Department of Fisheries Management, BAU, Mymensingh, Bangladesh.

Zhang, X., Xie, P., Hao, L., Guo, N., Gong, Y., Hu, X., Chen, J. and Liang, G., 2006. Effects of the phytoplanktivorous silver carp (Hypophthalmichthys molitrix) on plankton and the hepatotoxic microcystins in an enclosure experiment in a eutrophic lake, Lake Shichahai in Beijing. Aquaculture, 257: 173-186. 